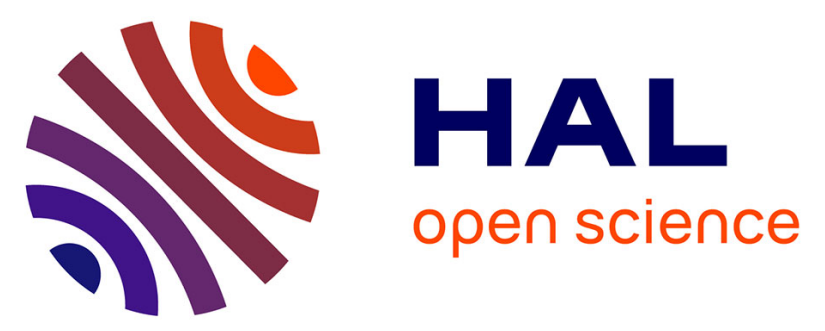

\title{
DNA methylation and potential multigenerational epigenetic effects linked to uranium chronic low-dose exposure in gonads of males and females rats
}

Ghada Elmhiri, Celine Gloaguen, Stephane Grison, Dimitri Kereselidze, Christelle Elie, Karine Tack, Marc Benderitter, Philippe Lestaevel, Audrey Legendre, Maamar Souidi

\section{To cite this version:}

Ghada Elmhiri, Celine Gloaguen, Stephane Grison, Dimitri Kereselidze, Christelle Elie, et al.. DNA methylation and potential multigenerational epigenetic effects linked to uranium chronic lowdose exposure in gonads of males and females rats. Toxicology Letters, 2018, 282, pp.64-70. 10.1016/j.toxlet.2017.10.004 . hal-02635731

\section{HAL Id: hal-02635731 \\ https://hal.science/hal-02635731}

Submitted on 27 May 2020

HAL is a multi-disciplinary open access archive for the deposit and dissemination of scientific research documents, whether they are published or not. The documents may come from teaching and research institutions in France or abroad, or from public or private research centers.
L'archive ouverte pluridisciplinaire HAL, est destinée au dépôt et à la diffusion de documents scientifiques de niveau recherche, publiés ou non, émanant des établissements d'enseignement et de recherche français ou étrangers, des laboratoires publics ou privés.

\section{(ㅇ)(1) $\$$}

Distributed under a Creative Commons Attribution - NonCommercial - NoDerivatives $\mid 4.0$ 


\section{Accepted Manuscript}

Title: DNA methylation and potential multigenerational epigenetic effects linked to uranium chronic low-dose exposure in gonads of males and females rats

Authors: G. Elmhiri, C. Gloaguen, S. Grison, D. Kereselidze, C. Elie, K. Tack, M. Benderitter, P Lestaevel, A. Legendre, M.

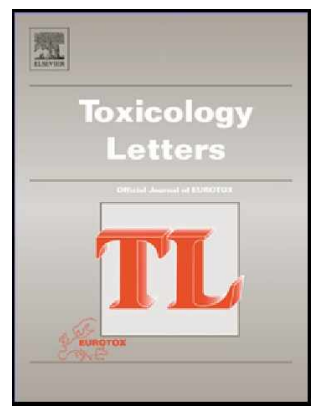
Souidi

PII:

DOI: S0378-4274(17)31381-4

Reference: https://doi.org/10.1016/j.toxlet.2017.10.004

TOXLET 9970

To appear in: $\quad$ Toxicology Letters

Received date: $\quad 15-5-2017$

Revised date: $\quad 28-8-2017$

Accepted date: $\quad$ 2-10-2017

Please cite this article as: Elmhiri, G., Gloaguen, C., Grison, S., Kereselidze, D., Elie, C., Tack, K., Benderitter, M., Lestaevel, P, Legendre, A., Souidi, M., DNA methylation and potential multigenerational epigenetic effects linked to uranium chronic low-dose exposure in gonads of males and females rats.Toxicology Letters https://doi.org/10.1016/j.toxlet.2017.10.004

This is a PDF file of an unedited manuscript that has been accepted for publication. As a service to our customers we are providing this early version of the manuscript. The manuscript will undergo copyediting, typesetting, and review of the resulting proof before it is published in its final form. Please note that during the production process errors may be discovered which could affect the content, and all legal disclaimers that apply to the journal pertain. 
DNA methylation and potential multigenerational epigenetic effects linked to uranium chronic low-dose exposure in gonads of males and females rats

Elmhiri $\mathrm{G}^{1}$., Gloaguen $\mathrm{C}^{1}$., Grison $\mathrm{S}^{1}$., Kereselidze. $\mathrm{D}^{1}$., Elie. $\mathrm{C}^{1}$, Tack $\mathrm{K}^{1}$., Benderitter $\mathrm{M}^{2}$. Lestaevel. $\mathrm{P}^{1}$., Legendre $\mathrm{A}^{1}$ and Souidi $\mathrm{M}^{1 *}$

*Corresponding author:

Phone: +33158359194,

Fax: +33158358467 ,

E-mail: maamar.souidi@irsn.fr

${ }^{1}$ Institut de Radioprotection et de Sûreté Nucléaire (IRSN), PRP-HOM, SRBE, LRTOX, Fontenay-aux Roses, France; ${ }^{2}$ Institut de Radioprotection et de Sûreté Nucléaire (IRSN), PRPHOM, SRBE, Fontenay-aux Roses, France; ${ }^{3}$ Institut de Radioprotection et de Sûreté Nucléaire (IRSN), PRP-HOM, Fontenay-aux Roses, France.

\section{Graphical abstract}

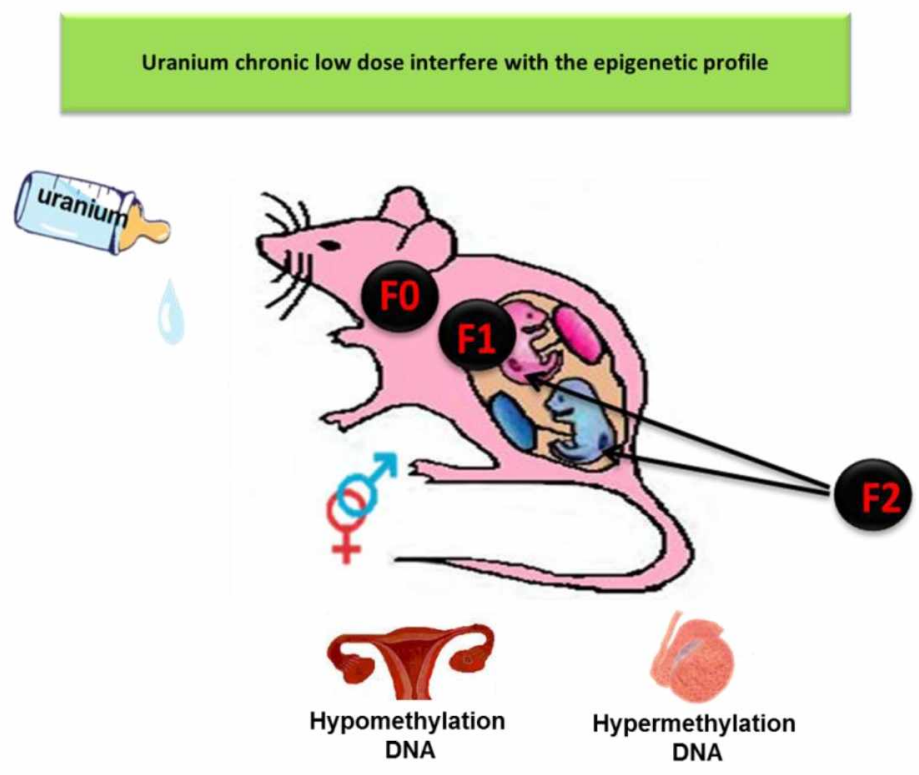




\title{
Research Highlights
}

- Exposure to uranium low dose on a rat model, male and female, induces global DNA methylation changes in F0 gonads.

- $\quad$ The changes are conserved through F1 and F2 generations.

- -These modifications are associated with variations in methylation /demethylation gene expression.

\begin{abstract}
Introduction: An increased health problem in industrialised countries is the contemporary concern of public and scientific community as well. This has been attributed in part to accumulated environmental pollutants especially radioactive substances and the use of nuclear power plants worldwide. However, the outcome of chronic exposure to low doses of a radionuclide such as uranium remains unknown. Recently, a paradigm shift in the perception of risk of radiotoxicology has emerged through investigating the possibility of transmission of biological effects over generations, in particular by epigenetic pathways. These processes are known for their crucial roles associated with the development of several diseases.

Objective: The current work investigates the epigenetic effect of chronic exposure to low doses of uranium and its inheritance across generations. Materials and Methods: To test this proposition, a rodent multigenerational model, males and females, were exposed to a non-toxic concentration of uranium ( $40 \mathrm{mg} \mathrm{L}^{-1}$ drinking water) for nine months. The uranium effects on were evaluated over three generations (F0, F1 and F2) by analysing the DNA methylation profile and DNMT genes expression in ovaries and testes tissues.
\end{abstract}

Results: Here we report a significant hypermethylation of testes DNA $(p<0.005)$ whereas ovaries showed hypomethylated DNA ( $\mathrm{p}<0.005)$. Interestingly, this DNA methylation profile was significantly maintained across generations F0, F1 and F2. Furthermore, qPCR results of both tissues imply a significant change in the expression of DNA methyltransferase genes (DNMT 1 and DNMT3a/b) as well. Conclusion: Altogether, our work demonstrates for the first time a sex-dependance and inheritance of epigenetic marks, DNA methylation, as a biological 
response to the exposure to low doses of uranium. However, it is not clear which type of reproductive cell type is more responsive in this context.

\section{Keywords}

DNMTs, TET, global DNA methylation, epigenetic, gonads; multigenerational model, uranium, chronic low-dose

\section{Introduction}

Environmental risks have been linked to significantly impact human health. Although, the specific contribution of environmental factors to the distribution of health and diseases can not be previously determined. The recognition that exposure to environmental toxic including radiation could produce DNA damage is a major mark. Recent evidence suggest that molecular influence of the environment may extend beyond the interaction with DNA.

Epigenetics corresponds to the study of changes in gene activity, without modification of the DNA sequence. Epigenetic changes are reversible and can be transmitted to multiple generations. The most commonly studied mechanism is DNA methylation defined by the addition of a methyl group at the carbon 5 of cytosine. DNA methylation is an epigenetic regulatory mechanism critical for proper development, with central roles in genome stability, $\mathrm{X}$ chromosome inactivation, and genomic imprinting (Bird, 1992; Russo V.E.A. et al., 1996). This epigenetic process is controlled at several different levels in cells and is carried out by a group of enzymes called DNA methyltransferases (DNMTs) which are required for establishment and maintenance of DNA methylation patterns.

Radionuclides such as uranium are ubiquitous chemicals that interfere with growth and development. Several radionuclides also interfere with epigenetic programming (Merrifield and Kovalchuk, 2013; Xin et al., 2015). The heritable nature of epigenetic changes also raises the risk for transgenerational inheritance of phenotypes (Angers et al., 2010).

Recently, several in vivo studies have shown that uranium can affect different physiological processes like intestinal inflammatory pathways, the reproductive system, brain, antioxidant system, and xenobiotic metabolisms (Briner, 2010; Dublineau et al., 2006; Feugier et al., 2008; 
Legendre et al., 2016; Lestaevel et al., 2009; Souidi et al., 2009). Recent studies in vivo demonstrate that $U$ has an epigenetic effect particularly in DNA methylation process (Gombeau et al., 2016; Miller et al., 2009; Su et al., 2006). However, the epigenetic consequences of longterm effects of low-dose natural uranium contamination on health across generation are still unknown.

To mimic environmental contamination, especially among children, who are identified as the vulnerable population, in our multigenerational model, male and female rats were chronically exposed from birth to adulthood over a continuous 9-month period.

The aim of the current investigation was to establish for the first time (i) whether low dose chronic exposure to Natural Uranium (NU) could induce epigenetic effects (DNA methylation) in gonads of rats, (ii) whether the methylation and demethylation enzymes gene expression displayed some degree of sex-dimorphism, (iii) and whether these effects could be conserved across generations.

\section{Material and methods}

\subsection{Experimental design and contamination}

All experimental procedures were approved by the Animal Care Committee of the Institute of Radioprotection and Nuclear Safety (IRSN) and complied with French regulations for animal experimentation (Ministry of Agriculture Act No.87-848, October 19, 1987, modified May 20, 2001).

Sprague-Dawley rats, 12 weeks old and 16 days pregnant, were obtained from Charles River Laboratories (L'Arbresle, France). They were housed individually and maintained in a $12 \mathrm{~h}$ light/ $12 \mathrm{~h}$ dark cycle (regular cycle) at $21^{\circ} \mathrm{C}$ and $50 \%$ humidity, with access ad libitum to a standard rodent pellet diet and water. After weaning, mothers were euthanised because they were not utilized in the study. Male and female offsprings were housed, each paired with a rat from a different mother (assigned by randomization).

Three generations of male and female rats (F0, F1 and F2) were generated: indeed, F0 generation male and female rats were contaminated via drinking water supplemented with NU at a concentration of $40 \mathrm{mg} \mathrm{L}^{-1}$ (dose about $1 \mathrm{mg} \cdot \mathrm{day}^{-1}$ per rat) from birth until nine months of age. 
The dose of NU ranged from triple the highest uranium concentration of $12.4 \mathrm{mg} \mathrm{L}^{-1}$ naturally founded, in water in Finland (Salonen, 1994).Experiments were performed using natural uranium $\left(\mathrm{UO}_{2}\right)$ (Olympic) was obtained from CERCA (Pierrelatte, France) (Grison et al., 2013). F1 generation male and female rat's offsprings were exposed to $\mathrm{NU}$ in utero and throughout lactation via the mother's milk after birth until weaning corresponding to postnatal day 21 . After weaning, F1's rats were not directly exposed to NU until they reached nine months of age. F2 male and female offspring rats were not exposed directly to NU. Control female and male drank non-contaminated water. NU was dissolved in mineral water and prepared in its uranyl nitrate hexahydrate and presented a specific activity of $2.42 \times 10^{+4} \mathrm{~Bq} \cdot \mathrm{g}^{-1}$.

\subsection{Measurement of natural uranium accumulation}

After removing, testes and ovaries were stored at $-20^{\circ} \mathrm{C}$. Samples were prepared by adding $8 \mathrm{~mL}$ of $69 \%$ nitric acid (ARISTAR) and $2 \mathrm{~mL}$ of $30 \%$ hydrogen peroxide. Samples were then mineralized using a $1000 \mathrm{~W}$ microwave (Ethos Touch; Milestone Microwave Laboratory Systems, Italy) with a $20 \mathrm{~min}$ ramp to $180^{\circ} \mathrm{C}$, followed by $10 \mathrm{~min}$ at $180^{\circ} \mathrm{C}$. The uranium content of samples was determined using an inductively coupled plasma mass spectrometer (ICP-MS X series 2, Thermo Electron France) with bismuth $\left(1 \mu \mathrm{g} \cdot \mathrm{L}^{-1}\right)$ as internal standard. For uranium,

ICPMS limit detection was $10^{-4} \mu \mathrm{g} \cdot \mathrm{L}^{-1}$. Five measurements were performed per sample. Values were expressed as nanograms per gram of fresh tissue. The quantification limit of uranium is 1 ng. $\mathrm{L}^{-1}$.

\subsection{Epigenetics analysis in testes and ovaries}

\subsubsection{DNA extraction and global DNA methylation}

Testes and ovaries were snap-frozen without albuginea in liquid nitrogen, and stored at $-80 \circ \mathrm{C}$.

DNA from $10 \mathrm{mg}$ ovaries and testes tissues was extracted using the QIAmp Mini kit (Qiagen, France) according to the manufacturer's instructions.

The difference in methylation profile in the testes and ovaries tissues was identified using 5-mC DNA ELISA kit (Zymoresearch, California, USA). The methylation level of gDNA samples was elucidated as per the protocol and guidelines mentioned in the kit. The negative and positive 
controls consisting of $100 \mathrm{ng} / \mu \mathrm{L}$ double-stranded DNA, was included in each run. The standard curve was prepared using multiple combinations of negative and positive controls according to manufacturer's instruction. The absorbance was measured at $450 \mathrm{~nm}$ using TECAN reader (Infinite ${ }^{\circledR} 200$ PRO NanoQuant Plate Reader). The results were validated using duplicate samples.

\subsubsection{RNA extraction and $q P C R$}

Total RNA was extracted from testes and ovaries samples, using mirVana ${ }^{\mathrm{TM}}$ miRNA Isolation Kit (Ambion, cat.no.1560). The NanoDrop apparatus (ThermoFisher Scientific, Cergy Pontoise, France) was used for determining the concentration of RNA $n g / \mu \mathrm{L}$. $1 \mu \mathrm{g}$ of total RNA was reversely transcribed using High-Capacity cDNA Reverse Transcription Kit (Applied Biosystems, Courtaboeuf, France) according to the manufacturer's instructions. Real-time qPCR was performed with QuantStudio 12K Flex Real-Time PCR System (ThermoFisher Scientific, Cergy Pontoise, France) using TAQMAN (Applied Biosystems), to analyse the mRNA levels of demethyls genes TET1 (Rn01428192_m1), TET2 (Rn01522037_m1), TET3 (Rn01425643_m1), TDG (Rn00821513_ml), and using SYBER Green® (Applied Biosystems) to analyse the mRNA levels of methyltransferases: DNMT1, DNMT3a, DNMT3b, DNMT31 (Table 1), Relative quantification in genes mRNA expression in gonads were calculated with real efficiency of each couple of primers using e- $\triangle \mathrm{CT}$ method and HPRT, $\beta 2 \mathrm{M}$ and ACTB as internal controls. All samples were normalised to three most stably expressed genes in rat testes and ovaries: ACTB, b microglobulin 2 (bmg 2) and hypoxanthine-guanine phosphoribosyltransferase (HPRT). In order to normalise the mRNA expression of target genes, we used the geometric mean of these three referenced genes. All RT-qPCR results are expressed as mean \pm SEM and compared to expression levels of the non-exposed group.

\section{Statistical Analysis}

Results are expressed as mean \pm SEM (Standard Error of Mean), Student's t-test was routinely performed for statistical analysis of data, and was replaced by Mann-Whitney Rank Sum Test when the equal variance test failed (determined by Sigmaplot Stat software). Differences were considered statistically significant when $\mathrm{p} \leq 0.05$ 


\section{Results:}

\subsection{Health Parameters}

The chronic low dose exposure to NU didn't change food intake, water consumption (data not shown) and organ (ovaries and testes) weights for the generations F0 and F1, as they were compared to their age-matched control groups (Table 2).

Although, exposure to NU increased significantly relative ovaries and testes weight of the generation F2 compared to control rats (Table 2).

\subsection{Uranium quantification in testes and ovaries}

Uranium concentrations in the gonads of F0 male and female rats exposed to $40 \mathrm{mg} \cdot \mathrm{L}^{-1} \mathrm{NU}$ were significantly increased compared to control rats (2-fold testes, 3-fold ovaries) (Table 3). As for the $2^{\text {nd }}$ generation (F1), no significant difference was observed between rats exposed and controls ones (Table 3).

\subsection{Global DNA methylation}

The first generation (F0) analyses reveal a hypermethylation (17\%) in testes tissue; however, DNA in ovaries was significantly hypomethylated (18\%) (Figure1 A and B). In F1 and F2 testes tissue, we observed a DNA hypermethylation (41\%) and (32\%) respectively (Figure $2 \mathrm{~A}$ and C). In contrary, in F1 and F2 ovaries tissue, DNA was significantly hypomethylated (41\% and $21 \%$, respectively) (Figure $2 \mathrm{~B}$ and $\mathrm{D})$.

\subsection{DNA methyltransferases genes expression}

The gene expression of the methylation enzyme DNMT3L was significantly decreased ( $p<$ 0.001) only in F0 male rats exposed to NU compared to control ones (Figure $3 \mathrm{~A}$ ). On the other hand, we showed an overexpression of DNMT1 (p <0.01) (F2) and DNMT3a (F1 and F2) (p $<0.001$ ) methylation enzymes genes compared to the control rats (Figure $3 \mathrm{C}$ and $\mathrm{E}$ ). 
Concerning the expression of the methyltransferases genes in $\mathrm{F} 0$ female rats, we did not observe any differences between the two groups of rats. In contrary, we showed an overexpression of methylation enzymes genes of DNMT1, DNMT3b and DNMT3L in the ovaries of the NU exposed generation $\mathrm{F} 1$ compared to the controls ones. For the generation F2, only a significant overexpression of DNMT1 gene ( $<0.001$ ) was observed (Figure 3 B, D and F) in NU group compared to control group.

\subsection{DNA demethylation genes expression (TETs, TDG)}

We did not observe any modification of the gene expression of the enzymes involved in the demethylation (TET and TDG) in the ovaries of the three generations compared to control (Figure $4 \mathrm{~B}, \mathrm{D}$ and F). Therefore, in testes, NU exposure did not induce a significant effect on the gene expression of these enzymes for the generations F0 and F1 (Figure 4 A and B). Nonetheless, we demonstrated, in the ovaries tissue of the generation F2, a significant decrease in the expression of demethylases in NU group compared to control group (Tet 2, Tet 3 and TDG) (Figure 4 E).

\section{Discussion}

Current understanding of molecular basis of major diseases relies on mechanisms beyond genetic mutations and transcription factors (Denis, 2010). Therefore, epigenetic changes, especially DNA methylation, that are mitotically stable represent a novel mechanism through which gene expression and cellular phenotypes are regulated (Wolffe and Guschin, 2000). It is widely accepted that environmental stress alters epigenetic marks, which in turn may lead to the development of diseases (Lo and Zhou, 2014). Previous studies demonstrated that exposure to low doses of chemical compounds dispersed in the environment can significantly impact biological, behavioural and metabolomics processes (Bonvallot et al., 2013; Dudka et al., 2014; Grison et al., 2016; Rochester, 2013; Xu et al., 2013). However, in the field of radioprotection, few studies have reported the epigenetic effects mediated by exposure to low doses of radionuclides. With this, we showed epigenetic effects of chronic exposure, via drinking water, to supra-environmental NU dose. First, we were interested in uncovering an epigenetic change in 
gonads induced by chronic exposure to low doses of NU. Furthermore, a comparison of the gender-related response to NU to reveal any sexual dimorphism associated with exposure. Our results demonstrated that NU exposure affected the global DNA methylation status in the first generation of rats F0. We further found that the global epigenetic profile was conserved both in F1 and F2 gonads of male and female rats, though the modification of the methylation profile is not identical. For the first time, we report that chronic low-dose exposure to NU for nine months affects the total genome-wide cytosine methylation in male and female rats. In first generation (F0), global increases in methylated cytosine were detected in the testes while gonads of female rats showed hypomethylation of genomic DNA. This global DNA methylation profile is sex-and tissue-specific. This could be linked to the significant accumulation of uranium in gonads of the first generation as confirmed, in the same animal model, by (Paquet et al., 2006). Our present finding of hypomethylation in F0 ovaries and hypermethylation in F0 testes, suggest that chronic low-dose exposure to NU induces a differential sex and tissue-dependent response.

A recent in vivo study carried out on zebrafish model (Daino rerio) has revealed that $\mathrm{U}$ induced DNA methylation in the gonads, eyes and brain (Gombeau et al., 2016). In rat's model, exposure to $\mathrm{U}$ induced a hypermethylation in renal tissue (Souidi M. et al., 2016). Furthermore, in workers at Chinese uranium mining, Su et al. have previously reported that the methylation rate of tow genes involved in lung cancer was increased significantly with the cumulative doses of radon, a uranium radioactive daughters (Su et al., 2006).

In the current study, epigenetic changes observed in males and female F0 rats were not associated with harmful effects as has been shown previously (Grison et al., 2016) which suggest that our experimental model was adapted to the chronic low dose exposure of NU. The next question is: Are these epigenetic effects preserved over the following generations F1 and F2? Indeed, these epigenetic effects could be reversible but also could be transmitted over generations (Heard and Martienssen, 2014). In the current study for the first time, we demonstrated in our multigenerational experimental model that global DNA hypermethylation in male rats and DNA hypomethylation in females were stable and conserved on male and female gonads for F1 and F2 generations.

This epigenetic signature is one more time sex and tissue dependent. The stability of this epigenetic mark could be explained by the direct multigenerational exposure of parents (F0) and subsequent generations (F1 / In utero (fetus), and with an indirect way (F2 / In utero (gonads of 
the fetus). The mechanism of heredity could also explain the conservation of this signature through the generations (Angers et al., 2010; Heard and Martienssen, 2014). Indeed, it has been shown in other experimental models exposed to other types of environmental pollutants that DNA methylation is transmitted over generations ( $\mathrm{Li}$ et al., 2014).

DNA methylation is dependent on a family of enzymes, methyltransferase and demethyltransferase, which plays a crucial role in the establishment of these epigenetic marks (Zhang and $\mathrm{Xu}, 2017$ ). DNA methyl-transferase (DNMT) enzymes catalyse the addition of a methyl group to the cytosine base within a $\mathrm{CpG}$ dinucleotide context and methylation in gene promoters is typically associated with transcriptional repression (Schubeler, 2015). Additionally, other modifications to DNA have been described, including the conversion of methyl cytosine to hydroxymethyl-, carboxyl-, and/or formylcytosine as part of a multi-step DNA demethylation process (Schubeler, 2015). These modifications are catalysed by (TET) enzymes (Tahiliani et al., 2009); the function of each intermediate modification, however, remains to be determined. It has been shown that a disturbance of the methylation-demethylation cycle induces a deleterious or lethal effect (Chen and Riggs, 2011). In our study, gene expression of methyltransferases (DNMT1, DNMT 3a, 3b, 3L) was affected by $\mathrm{U}$ exposure in both sexes in the three generations.

In the present study, NU exposure induced a modification in the gonads of exposed adult rats.

Indeed, in the testes the overexpression of the DNMTs genes (DNMT1 (F0/F2) and DNMT3a (F1/F2), associated with a downregulation of TET and TDG (only in the F2 generation) could explain the hypermethylation of the DNA in this organ. Several studies have shown correlations between the expression of these genes and the level of DNA methylation (Chen et al., 2014). On the other hand, in the ovaries, the overexpression of these methyltransferases could be linked to a system of compensation of the overall hypomethylation observed in the females. This hypomethylation could explain the absence of modification in the gene expression of the TETs and TDG involved in the DNA demethylation, although this is still unproven.

Nevertheless, we did not observe any relationship between the DNA methylation patterns and the level of expression of genes involved in the methylation and demethylation of DNA. More generally, it is also not possible to establish a link between DNA methylation patterns and the transcriptomic response. The lack of correlation between the transcriptomic data and DNA methylation may well be due to post-transcriptional effects influencing the regulation of the activity of enzymes involved in DNA methylation, such as phosphorylation/dephosphorylation, 
allosteric effects, cofactor activation or sub-unit recruitment. Although the DNA methylation mechanism can control the expression of genes, the DNA methylation sites are spread throughout the genome and not merely in the regulatory elements of the promoters of genes, and we did not have assessed the methylation status of targeted promoters. Furthermore, a gene's level of expression is not necessarily linked with the level of DNA methylation in its regulatory elements, and many other mechanisms such as phosphorylation/dephosphorylation of transcription factors and chemical modifications of histones are known. As a result, it would seem to suggest a potential link such as the correlation between the DNA methylation level and the transcriptomic response of methyltransferases and demethyltransferases genes.

\section{Conclusion}

For the first time, in radiotoxicology, we demonstrate that chronic low-dose exposure of uranium affects the global methylation profile in the gonads. Interestingly, this sex-dependent epigenetic signature has been conserved across generations and associated with a modification of gene expression of the methyltransferases/ demethyltransferases system. The observed modulations of DNA methylation provide evidence for the concept of the existence of epigenetic effects following chronic low-dose contamination of uranium. These results raise the question of the physiological relevance of these epigenetic fingerprints and their importance in the fate of the individual and his offspring regarding radiation protection. Employing the precautionary principle in the context of chronic low doses of radionuclides may help reduce the incidence of various diseases with currently unknown aetiology.

Conflict of Interest statement: The authors have no conflicts of interest relevant to this article to disclose.

Funding: Institut de radioprotection et sureté nucléaire (IRSN) 


\section{References:}

Angers, B., Castonguay, E., Massicotte, R., 2010. Environmentally induced phenotypes and DNA methylation: how to deal with unpredictable conditions until the next generation and after. Mol Ecol 19, 1283-1295.

Bird, A., 1992. The essentials of DNA methylation. Cell 70, 5-8.

Bonvallot, N., Tremblay-Franco, M., Chevrier, C., Canlet, C., Warembourg, C., Cravedi, J.P., Cordier, S., 2013. Metabolomics tools for describing complex pesticide exposure in pregnant women in Brittany (France). PLoS One 8.

Briner, W., 2010. Toxicity from metals, old menaces and new threats. Int J Environ Res Public Health 7, 4278-4280.

Chen, C., Zhang, C., Cheng, L., Reilly, J.L., Bishop, J.R., Sweeney, J.A., Chen, H.Y., Gershon, E.S., Liu, C., 2014. Correlation between DNA methylation and gene expression in the brains of patients with bipolar disorder and schizophrenia. Bipolar Disord 16, 790-799.

Chen, Z.X., Riggs, A.D., 2011. DNA methylation and demethylation in mammals. J Biol Chem 286, 1834718353.

Denis, G.V., 2010. Bromodomain coactivators in cancer, obesity, type 2 diabetes, and inflammation. Discov Med 10, 489-499.

Dublineau, I., Grison, S., Grandcolas, L., Baudelin, C., Tessier, C., Suhard, D., Frelon, S., Cossonnet, C., Claraz, M., Ritt, J., Paquet, P., Voisin, P., Gourmelon, P., 2006. Absorption, accumulation and biological effects of depleted uranium in Peyer's patches of rats. Toxicology 227, 227-239.

Dudka, I., Kossowska, B., Senhadri, H., Latajka, R., Hajek, J., Andrzejak, R., Antonowicz-Juchniewicz, J., Gancarz, R., 2014. Metabonomic analysis of serum of workers occupationally exposed to arsenic, cadmium and lead for biomarker research: a preliminary study. Environ Int 68, 71-81.

Feugier, A., Frelon, S., Gourmelon, P., Claraz, M., 2008. Alteration of mouse oocyte quality after a subchronic exposure to depleted Uranium. Reprod Toxicol 26, 273-277.

Gombeau, K., Pereira, S., Ravanat, J.L., Camilleri, V., Cavalie, I., Bourdineaud, J.P., Adam-Guillermin, C., 2016. Depleted uranium induces sex- and tissue-specific methylation patterns in adult zebrafish. J Environ Radioact 154, 25-33.

Grison, S., Fave, G., Maillot, M., Manens, L., Delissen, O., Blanchardon, E., Banzet, N., Defoort, C., Bott, R., Dublineau, I., Aigueperse, J., Gourmelon, P., Martin, J.C., Souidi, M., 2013. Metabolomics identifies a biological response to chronic low-dose natural uranium contamination in urine samples. Metabolomics 9, 1168-1180.

Grison, S., Fave, G., Maillot, M., Manens, L., Delissen, O., Blanchardon, E., Dublineau, I., Aigueperse, J., Bohand, S., Martin, J.C., Souidi, M., 2016. Metabolomics reveals dose effects of low-dose chronic exposure to uranium in rats: identification of candidate biomarkers in urine samples. Metabolomics 12 , 15.

Clark, A.T., 2015. DNA methylation remodeling in vitro and in vivo. Curr Opin Genet Dev. 34: 82-87. Legendre, A., Elie, C., Ramambason, C., Manens, L., Souidi, M., Froment, P., Tack, K., 2016. Endocrine effects of lifelong exposure to low-dose depleted uranium on testicular functions in adult rat. Toxicology 369, 58-68.

Lestaevel, P., Romero, E., Dhieux, B., Ben Soussan, H., Berradi, H., Dublineau, I., Voisin, P., Gourmelon, P., 2009. Different pattern of brain pro-/anti-oxidant activity between depleted and enriched uranium in chronically exposed rats. Toxicology 258, 1-9.

Li, G., Chang, H., Xia, W., Mao, Z., Li, Y., Xu, S., 2014. F0 maternal BPA exposure induced glucose intolerance of F2 generation through DNA methylation change in Gck. Toxicol Lett 228, 192-199.

Lo, C.L., Zhou, F.C., 2014. Environmental alterations of epigenetics prior to the birth. Int Rev Neurobiol $115,1-49$. 
Merrifield, M., Kovalchuk, O., 2013. Epigenetics in radiation biology: a new research frontier. Front Genet, doi: 103389/fgene201300040

Miller, A.C., Stewart, M., Rivas, R., 2009. DNA methylation during depleted uranium-induced leukemia. Biochimie 91, 1328-1330.

Paquet, F., Houpert, P., Blanchardon, E., Delissen, O., Maubert, C., Dhieux, B., Moreels, A.M., Frelon, S., Gourmelon, P., 2006. Accumulation and distribution of uranium in rats after chronic exposure by ingestion. Health Phys 90, 139-147.

Rochester, J.R., 2013. Bisphenol A and human health: a review of the literature. Reprod Toxicol 42, 132155.

Russo V.E.A., Martienssen R.A. , A.D., R., 1996. Epigenetic Mechanisms of Gene Regulation.

Salonen, L., 1994. $238 \mathrm{U}$ series radionuclides as a source of increased

radioactivity in groundwater originating from Finnish bedrock. Proceedings of the Helsinki conference. Schubeler, D., 2015. Function and information content of DNA methylation. Nature 517, 321-326.

Souidi, M., Tissandie, E., Racine, R., Ben Soussan, H., Rouas, C., Grignard, E., Dublineau, I., Gourmelon, P., Lestaevel, P., Gueguen, Y., 2009. [Uranium: properties and biological effects after internal contamination]. Ann Biol Clin 67, 23-38.

Souidi M., Gloaguen C. , Ibegazene O., Kereselidze D., Grison S., Manens L. , Elie C., Legendre A., Tack K., Aigueperse J., Dublineau I. , P., L., 2016. In vivo exposure to uranium induces reversible and irreversible effects on gene expression and epigenetics in adult male rats. Abstracts / Toxicology Letters 259S, S73S247.

Su, S., Jin, Y., Zhang, W., Yang, L., Shen, Y., Cao, Y., Tong, J., 2006. Aberrant promoter methylation of p16(INK4a) and O(6)-methylguanine-DNA methyltransferase genes in workers at a Chinese uranium mine. J Occup Health 48, 261-266.

Tahiliani, M., Koh, K.P., Shen, Y., Pastor, W.A., Bandukwala, H., Brudno, Y., Agarwal, S., Iyer, L.M., Liu, D.R., Aravind, L., Rao, A., 2009. Conversion of 5-methylcytosine to 5-hydroxymethylcytosine in mammalian DNA by MLL partner TET1. Science 324, 930-935.

Wolffe, A.P., Guschin, D., 2000. Review: chromatin structural features and targets that regulate transcription. J Struct Biol 129, 102-122.

Xin, F., Susiarjo, M., Bartolomei, M.S., 2015. Multigenerational and transgenerational effects of endocrine disrupting chemicals: A role for altered epigenetic regulation? Semin Cell Dev Biol 43, 66-75.

Xu, T., Holzapfel, C., Dong, X., Bader, E., Yu, Z., Prehn, C., Perstorfer, K., Jaremek, M., Roemisch-Margl, W., Rathmann, W., Li, Y., Wichmann, H.E., Wallaschofski, H., Ladwig, K.H., Theis, F., Suhre, K., Adamski, J., Illig, T., Peters, A., Wang-Sattler, R., 2013. Effects of smoking and smoking cessation on human serum metabolite profile: results from the KORA cohort study. BMC Med 11, 1741-7015.

Zhang, W., Xu, J., 2017. DNA methyltransferases and their roles in tumorigenesis. Biomark Res 5, 0170081. 


\section{FIGURES LEGENDS}

\section{Figure 1:}

Percentage of global DNA methylation assessed with ELISA (means \pm SEM) in the testis (A), ovaries (B) of the first generation F0. * Significantly different between the control C group $(\mathrm{n}=10)$ and uranium $\mathrm{U}(\mathrm{n}=10)$ groups $(* * \mathrm{p}<0.01 ; * * \mathrm{p}<0.001)$.

\section{Figure 2:}

Percentage of global DNA methylation assessed with ELISA (means \pm SEM) in the testis (A/ C), ovaries (B/D) of the second and third generation F1/ F2 respectively. *Significantly different between the control group $(n=10)$ and $U(n=10)$ groups $(* p<0.05 ; * *<0.01)$.

\section{Figure 3:}

Modification of DNA methyltransferase specific genes (DNMT1, DNMT3a and DNMT3b) mRNA expressions due to NU exposure in gonads of male and female rats for generations F0, F1 and F2. Blue bars represent male (testis) control group mRNA expression level (A, C and E). Pink bars represent female (ovaries) control group mRNA expression level (B, D and F). Black bars represent mRNA expression level of methyltransferase specific genes. Data are expressed as Mean \pm SEM (t-test). Significant difference between control $C(n=10)$ and uranium $U(n=10)$ groups. *: $\mathrm{P}<0.05$.

\section{Figure 4:}

Modification of DNA demethyltransferase specific genes (TET1, TET2, TET3 and TDG) expressions due to $\mathrm{U}$ exposure male and female rats for generations F0, F1 and F2. Blue bars represent male (testis) control group mRNA expression level (A, C and E). Pink bars represent female (ovaries) control group mRNA expression level (B, D and F). Black bars represent mRNA expression level of demethyltransferase specific genes. Data are expressed as Mean \pm SEM ( $t$ test). Significant difference between control $C(n=10)$ and uranium $U(n=10)$ groups. *: $P<0.05$. 


\section{FIGURES}

Figure 1

Fo
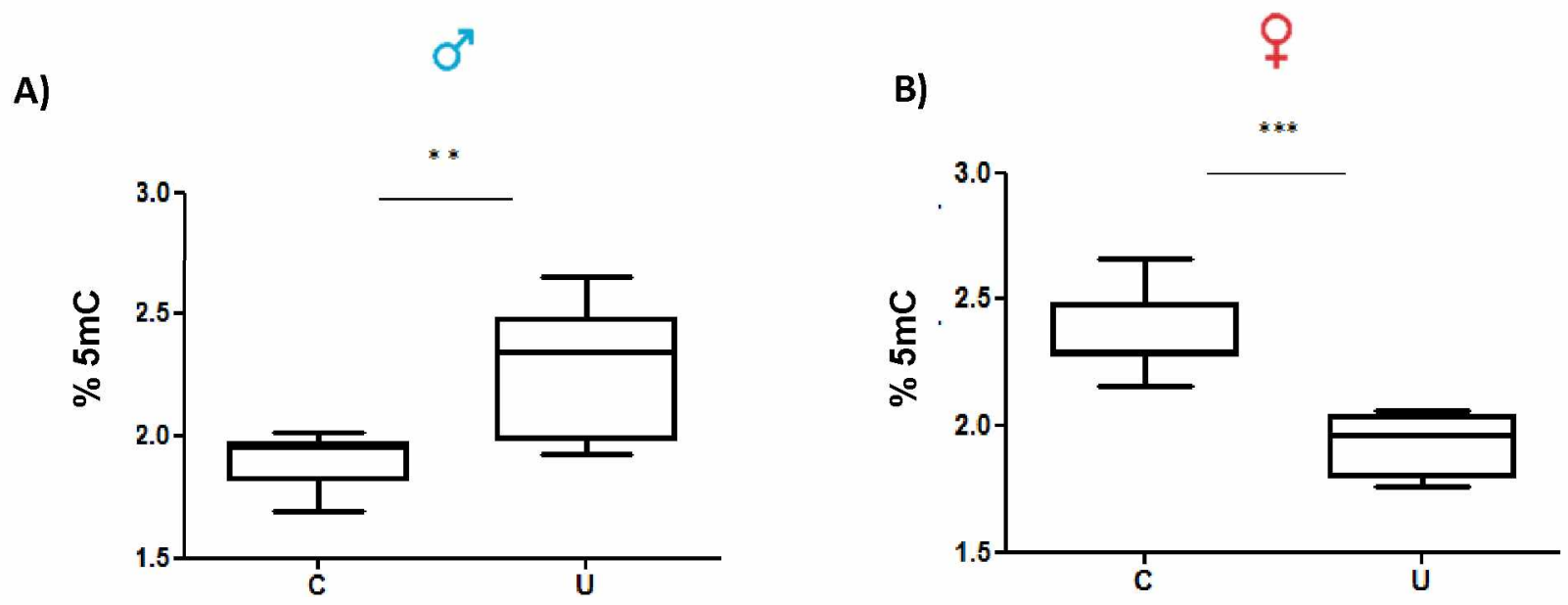
Figure 2

o

F1

F2

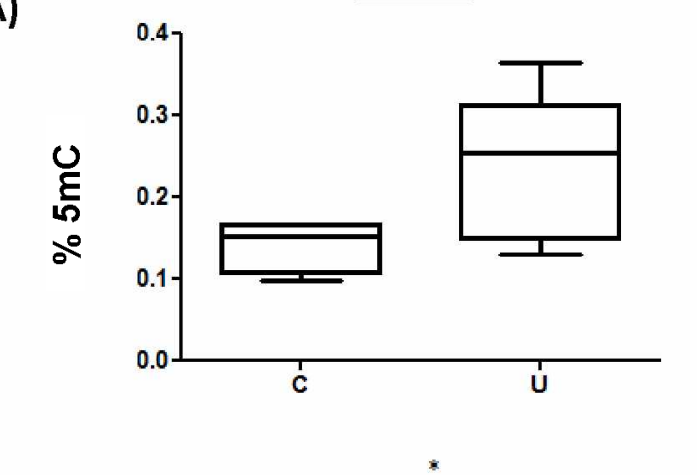

C)

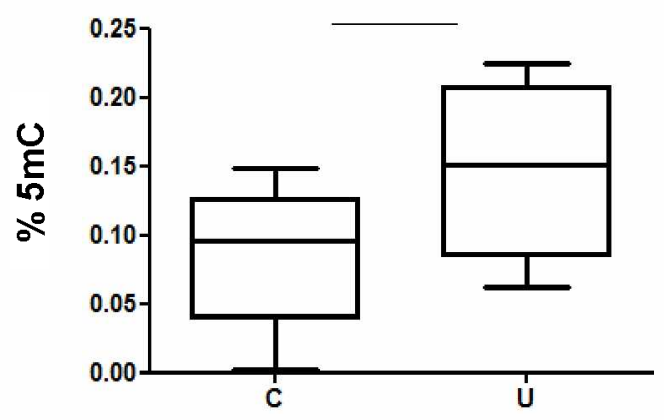

q

B)

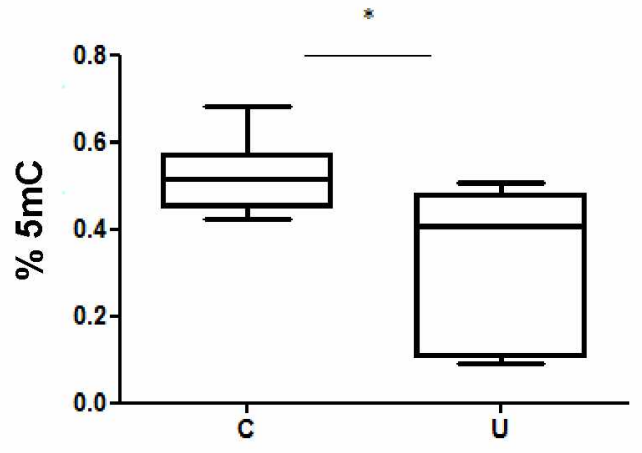

D)

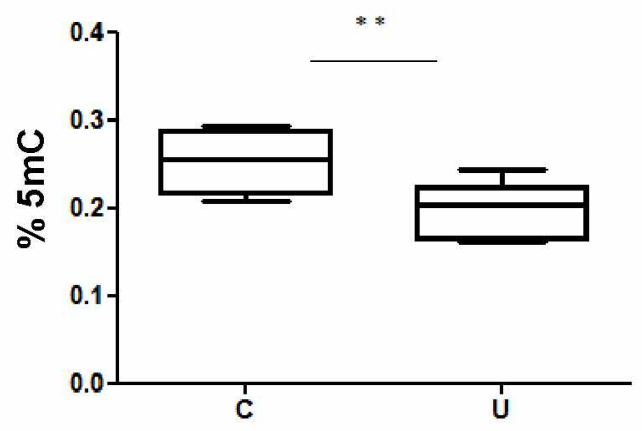


Figure 3
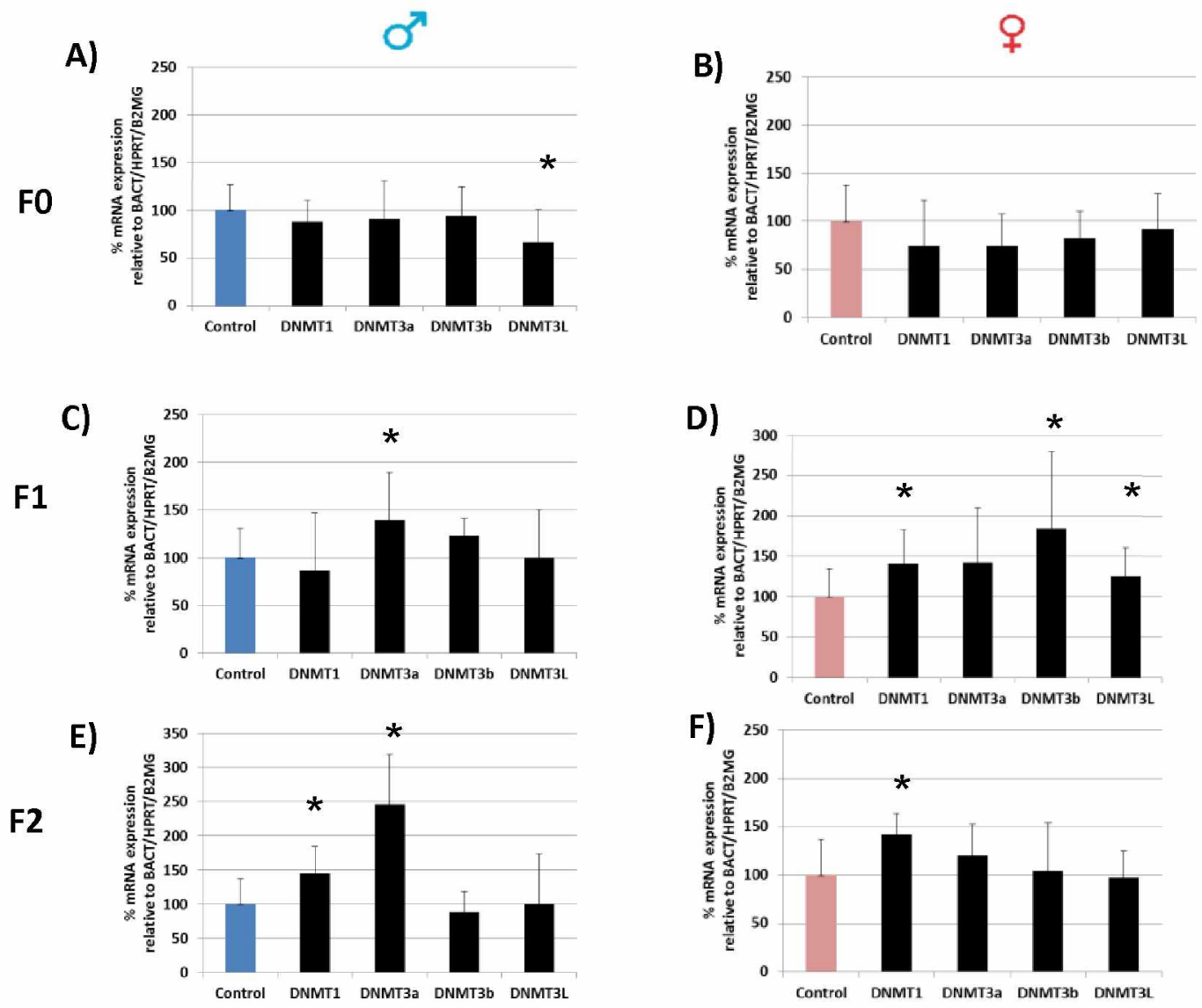
m

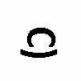

$\geq$

$\stackrel{7}{\stackrel{9}{9}}$

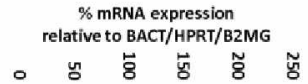

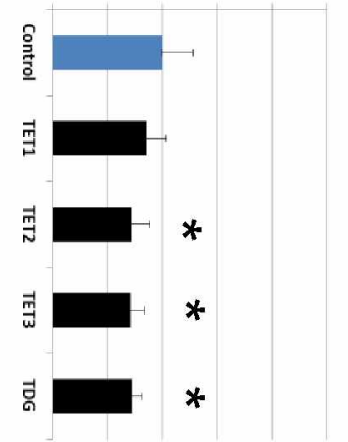

$\%$ mRNA expression

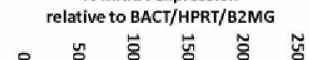

\% mRNA expression
relative to $B A C T / H P R T / B 2 M G$

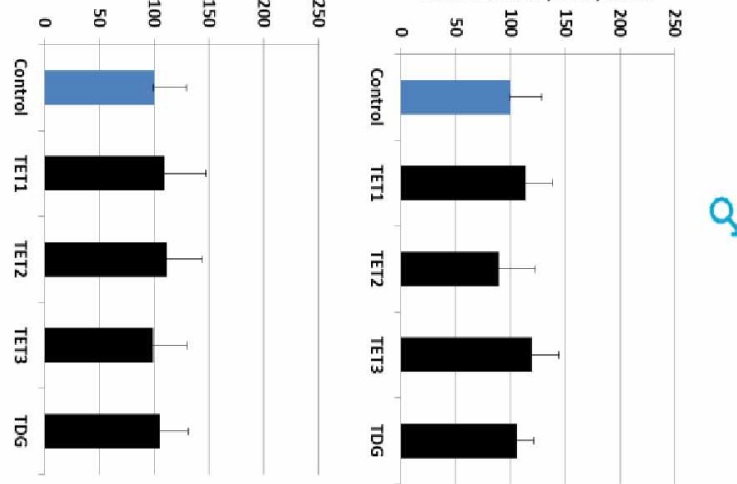

끄

므
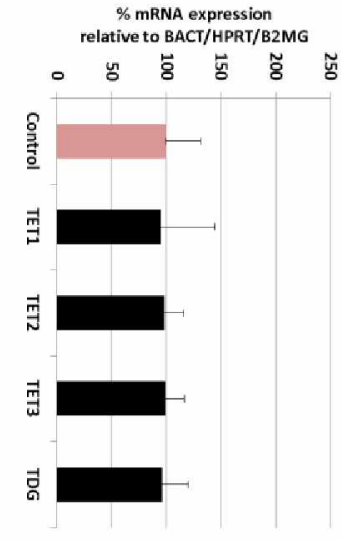

$\%$ mRNA expression
relative to $B A C T H H P R T / B 2 M G$
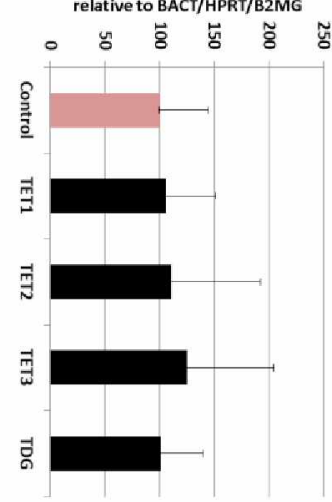

\% mRNA expression
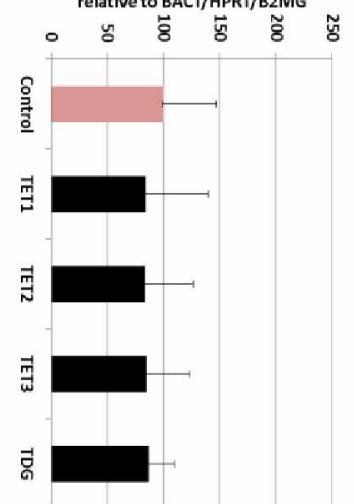

to 


\section{TABLE LEGENDS}

Table1: Sequence of primers set for gene expression studies in gonads.

\begin{tabular}{|c|l|}
\hline Genes & \multicolumn{1}{|c|}{ Sequences } \\
\hline DNMT1 & 5'-CGGCGGAGGTGTCCTAACTTGGC-3' \\
& 5'-GGGTGACGGCAACTCTGGTA-3' \\
\hline DNMT3a & 5'-CGGTAGCGCCTCTTCTTTGAGTTCTAC-3' \\
& 5'-GCGATCATCTCCCTCCTTGG-3' \\
\hline DNMT3b & 5'-GGGCCGCTACCACGTTCAGG-3' \\
& 5'-AGGGCCGTCCTGGCTCAAGT-3' \\
\hline DNMT3I (ovaries) & 5'-GTATGCCCGGCCTCGCCAAG-3' \\
& 5'-CAGGTCCGCGTGCTTGCTCT-3' \\
\hline DNMT3I (testes) & 5'-GCTTTGACGGTGGCGAGAA-3' \\
& 5'-TCTGCAAGAACTCGACCACAATC -3' \\
\hline
\end{tabular}


Table2: Whole-body weight and organ relatif weight of the three generations. Data are expressed as Mean \pm SEM (t-test). Significant difference between control $C(n=20)$ and uranium $\mathrm{U}(\mathrm{n}=20)$ groups $*: \mathrm{P}<0.05, * *: \mathrm{P}<0.01$

\begin{tabular}{|c|c|c|c|c|c|c|}
\hline & FO Control & FO U & F1 Control & F1 U & F2 Control & $\mathrm{F} 2 \mathrm{U}$ \\
\hline \multirow{2}{*}{\multicolumn{7}{|c|}{$\begin{array}{c}\text { Body weight } \\
\text { (g) }\end{array}$}} \\
\hline & & & & & & \\
\hline$\sigma^{x}$ & $626 \pm 83,2$ & $618 \pm 90,3$ & $524 \pm 78,6$ & $595 \pm 71,4^{*}$ & $579 \pm 68,9$ & $517 \pm 57,1^{* *}$ \\
\hline ? & $343 \pm 49,3$ & $331 \pm 42,2$ & $302 \pm 27,6$ & $322 \pm 84,3$ & $285 \pm 30,3$ & $262 \pm 40,6$ \\
\hline $\begin{array}{c}\text { Testes } \\
\text { (g) }\end{array}$ & $0,33 \pm 0,03$ & $0,32 \pm 0,05$ & $0,38 \pm 0,10$ & $0,36 \pm 0,05$ & $0,33 \pm 0,05$ & $0,38 \pm 0,06$ * \\
\hline $\begin{array}{l}\text { Ovaries } \\
\text { (g) }\end{array}$ & $1,530 \pm 0,002$ & $1,740 \pm 0,001$ & $1,74 \pm 0,08$ & $1,55 \pm 0,13$ & $1,840 \pm 0,07$ & $2,020 \pm 0,07$ * \\
\hline
\end{tabular}


Table3: Uranium quantification in gonads of the three rat's generations after 9 months chronic low dose exposure for 9 months. Data are expressed as Mean \pm SEM (t-test). Significant difference between control $\mathrm{C}(\mathrm{n}=5)$ and uranium $\mathrm{U}(\mathrm{n}=5)$ groups. ${ }^{* *}: \mathrm{P}<0.01$

\begin{tabular}{|c|c|c|c|c|}
\hline & \multicolumn{2}{|c|}{ Testes (U ng/g of tissue) } & \multicolumn{2}{|c|}{ Ovaries (U ng/g of tissue) } \\
\hline Generations & Control & Uranium & Control & Uranium \\
\hline F0 & $0.123 \pm 0.02$ & $1.193 \pm 1.06 * *$ & $2.422 \pm 0.16$ & $6.466 \pm 3.59 * *$ \\
\hline F1 & $0.098 \pm 0.03$ & $0.148 \pm 0.09$ & $2.823 \pm 0.47$ & $2.284 \pm 0.43$ \\
\hline F2 & $0.157 \pm 0.07$ & $0.286 \pm 0.33$ & $3.067 \pm 1.42$ & $3.771 \pm 0.69$ \\
\hline
\end{tabular}

